\title{
CHARAKTERYSTYKA INSTRUMENTÓW PRAWNYCH SŁUŻĄCYCH OCHRONIE RÓŻNORODNOŚCI BIOLOGICZNEJ W POLSCE
}

\section{DESCRIPTION OF LEGAL INSTRUMENTS SERVING THE PROTECTION OF BIOLOGICAL DIVERSITY IN POLAND}

\section{STRESZCZENIE}

Ochrona bioróżnorodności przyrodniczej wiąże się z koniecznością utrzymania równości biologicznej w ekosystemie. Nie jest to zadanie łatwe, w szczególności mając na uwadze postępującą techni-

* Magister prawa, Wydział Prawa i Administracji Uniwersytetu Kardynała Stefana Wyszyńskiego w Warszawie. 
kę i powszechną globalizację. Aby móc spełniać najwyższe standardy ochrony, powołane do tego zadania organy powinny dysponować odpowiednimi instrumentami prawnymi.

W takie instrumenty polski ustawodawca wyposaża kompetentne organy powołane do ochrony bioróżnorodności. Wśród nich można wyróżnić ustanowienie chociażby parków narodowych, rezerwatów przyrody, czy też pomników przyrody. Niniejszy artykuł stanowi komplementarny przegląd instrumentów prawnych służących ochronie bioróżnorodności w Polsce na gruncie ustawy z dnia 16 kwietnia 2004 r. o ochronie przyrody z uwzględnieniem najnowszych trendów i zagrożeń oraz ustawodawstwa Unii Europejskiej. Tekst został przygotowany na podstawie literatury przedmiotu, orzecznictwa oraz powszechnie obowiązującego prawa, zarówno polskiego jak i europejskiego.

\section{Słowa kluczowe}

Bioróżnorodność; ochrona różnorodności biologicznej; prawo ochrony przyrody; instrumenty prawne.

\section{ABSTRACT}

The protection of natural biodiversity requires the maintenance of biological equality in the ecosystem. It is not an easy task, particularly with a view to advancing technology and common globalization. To be able to meet the highest standards of protection, the authorities appointed to fulfil the task should have appropriate legal instruments.

The Polish legislator equips competent authorities designated for the protection of biodiversity in such instruments. Among them we can distinguish, for instance, the establishment of national parks, nature reserves or natural monuments. This article provides an overview of complementary legal instruments for the protection of biodiversity in Poland, taking into account the latest trends and threats, and the European Union legislation. The text has been prepared based on the literature, case law and common law, both Polish and European.

\section{Keywords}

Biodiversity; protection of biodiversity; environmental law; legal instruments. 


\section{WPROWADZENIE}

Termin bioróżnorodność (ang. biodiversity) po raz pierwszy został użyty przez Raymonda Dalesmana w książce, w której uzasadniał potrzebę ochrony przyrody. Fakt ten miał miejsce w 1968 r. Według niego, bioróżnorodność można określić jako zmienność żywych organizmów wszystkich środowisk występujących na Ziemi, włączając w to siedliska lądowe, morskie, inne ekosystemy wodne oraz ekologiczne kompleksy złożone z tych siedlisk; obejmuje ona zróżnicowanie wewnątrzgatunkowe, między gatunkami i zróżnicowanie ekosystemów. Bioróżnorodność tworzy podstawę szerokiego wachlarza świadczeń ekosystemów, który w istotny sposób kształtuje dobrobyt człowieka ${ }^{1}$. W sposób powszechny jednak do terminologii naukowej pojęcie to weszło w 1980 r., gdy zostało użyte przez Thomasa Lovejoya w przedmowie do książki Conservation Biology. Ta publikacja zainicjowała rozmowy naukowców na temat ochrony bioróżnorodności i samej definicji tego pojęcia.

Ochrona różnorodności biologicznej w XX w. doczekała się szerokiego ustawodawstwa oraz orzecznictwa. Takie zabiegi mają zagwarantować wysoki poziom ochrony różnych gatunków biologicznych. Prawo ochrony środowiska gwarantuje wiele rozwiązań mających zapewnić prewencję biologiczną oraz ustanawia instytucje prawne temu służące. Na gruncie niniejszego opracowania autor pragnie skupić się na genezie ochrony bioróżnorodności, jego ewolucji oraz instrumentach prawnych zagwarantowanych na gruncie ustawy z dnia 16 kwietnia 2004 r. o ochronie przyrody oraz niektórych aktów międzynarodowych i krajowych.

1 Millenium Ecosystem Assessment, MEA 2005. 


\section{DEFINICJA LEGALNA I CHARAKTERYSTYKA OCHRONY RÓŻNORODNOŚCI BIOLOGICZNEJ}

Bioróżnorodność, jako zjawisko nie doczekała się definicji legalnej w ustawodawstwie. Pomimo szeroko pojmowanej jurydyzacji w zakresie ochrony środowiska bioróżnorodność pozostaje określeniem pozaprawnym. Definicją legalną zostało za to objęte pojęcie różnorodności biologicznej. Zawarto ją w Konwencji o różnorodności biologicznej, sporządzonej w Rio de Janeiro dnia 5 czerwca 1992 r. $^{2}$ Zgodnie $\mathrm{z}$ art. 2 różnorodność biologiczna oznacza zróżnicowanie wszystkich żywych organizmów pochodzących, interalia, z ekosystemów lądowych, morskich i innych wodnych ekosystemów oraz zespołów ekologicznych, których są one częścią; dotyczy to różnorodności w obrębie gatunku, pomiędzy gatunkami oraz ekosystemami ${ }^{3}$.

Obecnie na świecie znanych jest ok. 1,4 mld gatunków. Z czego w Polsce występuje około 60000 z nich. Możemy wykazać, że spośród nich grzyby to w przybliżeniu 3630 gatunków, rośliny 16275 , pierwotniaki 1152 , a zwierzęta $35368^{4}$.

Co ciekawe, ponad połowa zarejestrowanych gatunków różnorodności biologicznej występuje w lasach równikowych ${ }^{5}$. Ostatnimi czasy obserwuje się ciągły spadek bioróżnorodności na świecie, co za tym idzie niektóre gatunki są skazane na całkowite wymarcie. W związku z powyższym ich ochrona stała się problemem nie tylko badaczy, ale także polityków, prawników i systemu administracyjnego. Waga powyższego zagadnienia powoduje podejmowanie działań ochronnych w prawnym systemie państwowym, a także na arenie międzynarodowej ${ }^{6}$. Bez

2 Ang. Convention on Biological Diversity, ratyfikowana przez Polskę 13 grudnia 1995.

3 Dz. U. z 2002 r. Nr 184, poz. 1532 z późn. zm.

4 R. Andrzejewski, A. Weigle, Różnorodność biologiczna Polski, Warszawa 2003, s. 10-24.

5 Jest to zgodne z zasadą wzrostu gradientu różnorodności w kierunku równika.

6 Wybrane problemy prawa ochrony środowiska, B. Rakoczy, M. Pchałek (red.), Warszawa 2010, s. 129-131. 
dobrze działających instrumentów prawnych bardzo ciężko byłoby zapewnić ochronę wszystkich tych gatunków.

Aby zapobiec zmniejszeniu bioróżnorodności na świecie, państwa - sygnatariusze konwencji o różnorodności biologicznej zobowiązały się do podjęcia działań chroniących to zjawisko.

Stosownie do art. 6 konwencji, każda umawiająca się strona, zgodnie ze swoimi szczególnymi warunkami i możliwościami:

- opracowuje krajowe strategie, plany lub programy dotyczące ochrony i zrównoważonego użytkowania różnorodności biologicznej bądź dostosowuje w tym celu istniejące strategie, plany lub programy, które odzwierciedlają interalia, działania przewidziane w konwencji, właściwe dla danej strony;

- włącza, w miarę możliwości i potrzeby, ochronę i zrównoważone użytkowanie różnorodności biologicznej do odpowiednich sektorowych i międzysektorowych planów, programów i polityk.

\section{SYSTEMY OCHRONY BIORÓŻNORODNOŚCI}

Ochrona bioróżnorodności to podejmowanie systemowych działań na rzecz trwałego zachowania wszystkich elementów różnorodności biologicznej w miejscach ich występowania naturalnego (ochrona in situ ${ }^{7}$ ), oraz zagrożonych gatunków, podgatunków i odmian poza miejscami ich naturalnego występowania bądź powstania (ochrona ex situ ${ }^{8}$ ).

7 Łac. in situ - na miejscu - ochrona gatunku chronionego, realizowana w jego naturalnym środowisku życia przez zachowanie niezmienionych warunków środowiskowych oraz zaniechanie pozyskiwania osobników tego gatunku lub dostosowanie rozmiarów i metod pozyskiwania do możliwości ich reprodukcji. Ochronie in situ służą przede wszystkim rezerwaty i parki narodowe. Por. art. 5 pkt 6 u.o.p.

8 Łac. ex situ - poza miejscem - ochrona gatunku chronionego realizowana przez przeniesienie go do ekosystemu zastępczego, gdzie może on dalej żyć samodzielnie w warunkach naturalnych, lub do środowiska sztucznie 
W ramach ochrony bioróżnorodności w 1992 r. w Rio de Janeiro została zwołana konferencja UNCED ${ }^{9}$ pt. Środowisko i Rozwój, znana szerzej jako Szczyt Ziemi ${ }^{10} .5$ czerwca tego roku została uchwalona, wcześniej przywołana już konwencja o różnorodności biologicznej.

Konwencja wprowadziła trzy poziomy ochrony przyrody: genetyczny, gatunkowy i ekosystemowy. Przy czym pojęcie ochrona rozumiane jest jako wiele przedsięwzięć polegających na zachowaniu różnorodności biologicznej na wszystkich jej poziomach, restytucji elementów utraconych, tworzeniu form gospodarowania zasobami różnorodności biologicznej. Dlatego też ważnym elementem pozostaje także monitoring bioróżnorodności, a także prowadzenie baz danych klasyfikujących poszczególne gatunki na obszarze całego kraju ${ }^{11}$.

\section{OCHRONA BIORÓŻNORODNOŚCI W POLSCE}

W Polsce pierwszą ocenę stanu bioróżnorodności biologicznej dokonano w 1991 r. Na jej podstawie opracowano dodatkowe dokumenty szczegółowe m.in.: Czerwoną księgę roślin i czerwona listę zwierząt ginących i zagrożonych (kręgowce i bezkręgowce), Czerwoną listę biotopów Morza Bałtyckiego, Ostoje ptaków w Polsce, Atlas rozmieszczenia $w$ Polsce siedlisk mokradłowych ${ }^{12}$.

stworzonego, w którym musi być otoczony stałą opieką człowieka. Przenoszone mogą być całe osobniki roślin albo ich nasiona, bulwy i kłącza. Ochronę ex situ mogą podejmować jedynie instytucje naukowe i urzędy konserwatorskie. W ten typ ochrony zaangażowane są głównie ogrody zoologiczne i ogrody botaniczne, gdzie prowadzone są badania zagrożonych gatunków, ich rozmnażanie i wymiana. Por. art. 5 pkt 7 u.o.p.

9 Ang. United Nations Conference on Environment and Development.

10 Konferencja Narodów Zjednoczonych na temat Środowiska i Rozwoju.

11 J. Ciechanowicz-McLean, Prawo i polityka ochrony środowiska, Warszawa 2009, s. 34-36.

12 Źródło [on-line]: http://www.strateg.gridw.pl/1_3.htm [dostęp: 9.05.2015]. 
Od strony prawnej przyrodę i środowisko jako dobro wspólne chroni Konstytucja Rzeczypospolitej Polskiej ${ }^{13} \mathrm{z}$ dnia 2 kwietnia 1997 r. a w szczególności art. 68 ust. 4 (obowiązek organów administracji do zapobiegania degradacji środowiska) oraz art. 74 ust. 2 (ochrona środowiska jako obowiązek władz publicznych). Ustawą szczegółową w niniejszym przedmiocie, która ma realizować postanowienia wcześniej wymienionej konwencji oraz Konstytucji RP jest ustawa z dnia 16 kwietnia 2004 roku o ochronie przyrody ${ }^{14}$ (w dalszej części opracowania u.o.p.).

W zakresie ochrony różnorodności biologicznej szczególnie istotny jest art. 46 u.o.p., który gwarantuje odpowiednią ochronę gatunkową gatunków oraz siedlisk i ostoi roślin, zwierząt i grzybów ${ }^{15}$. Stanowi on, że ochrona gatunkowa ma na celu zapewnienie przetrwania i właściwego stanu ochrony dziko występujących na terenie kraju lub innych państw członkowskich Unii Europejskiej rzadkich, endemicznych, podatnych na zagrożenia i zagrożonych wyginięciem ${ }^{16}$. Warto dodać, że Polskę obowiązują także postanowienia prawa Unii Europejskiej w niniejszym zakresie w tym m.in.: dyrektywy 92/43 habitatowej ${ }^{17}$ i dyrektywy 2009/147 - ptasiej ${ }^{18}$.

Wśród zagrożeń dla bioróżnorodności możemy wyróżnić następującą działalność i zjawiska: zmiany siedlisk - powierzchnia lasów ciągle się zmniejsza (szacuje się, że zmniejszyła się już z 50\% powierzchni całkowitej ziemi, do niespełna 30\%) w związku $\mathrm{z}$ tym ciągle giną kolejne gatunki zwierząt i roślin; zmiany klimatu - zmieniający się klimat i rosnąca temperatura wpływa na zmiany w rozmieszczeniu gatunków na ziemi, co wpływa na ekosystemy; ekspansja gatunków inwazyjnych - istnienie gatunków drapieżników, pasożytników, bądź przenoszących różnego rodzaju choroby powoduje likwidowanie innych,

13 Dz.U. 1997 nr 78 poz. 483 z późn. zm.

14 Tekst jedn. Dz. U. z 2015 r., poz. 1651 ze zm.

15 K. Gruszecki, Ustawa o ochronie przyrody. Komentarz, Warszawa 2013 s. $22-35$.

16 Por. art. 46 ust. 2 u.o.p.

17 Dz. Urz. UE L 206 z 1992 r., s. 7.

18 Dz. Urz. UE L 20 z 2010 r., s. 7. 
słabszych gatunków; nadmierna eksploatacja - przeciążenie ekosystemów powoduje ich niewydajność; zanieczyszczenia ${ }^{19}$.

Polska, stosownie do art. 6 Konwencji o różnorodności biologicznej podjęła się ustanowienia planów i strategii mających wpływać na ochronę bioróżnorodności. Zobowiązanie to zostało potwierdzone w II Polityce Ekologicznej Państwa, przyjętej przez Radę Ministrów 13 czerwca 2000 r., a następnie Sejm w sierpniu $2001 \mathrm{r}^{20}$. W dokumencie stwierdzono, że ochrona różnorodności biologicznej i krajobrazowej jest istotna dla zapewnienia bezpieczeństwa ekologicznego państwa, a zatem do zadań władz państwowych należy tworzenie warunków sprzyjających ochronie różnorodności biologicznej ${ }^{21}$. Za najważniejsze cele działań w tym zakresie uznano:

1) poprawę stanu środowiska - usunięcie lub ograniczenie zagrożeń dla zachowania różnorodności biologicznej i krajobrazowej,

2) zachowanie, odtworzenie i wzbogacanie zasobów przyrody,

3) osiągnięcie powszechnej akceptacji dla zachowania całości spuścizny przyrodniczej i kulturowej Polski ${ }^{22}$.

Zakres przedmiotowy ustawy o ochronie przyrody dotyczy ochrony przyrody ożywionej i nieożywionej oraz krajobrazu. W artykule 2 ust. 2 pkt 2 niniejszy akt stanowi, że celem ochrony przyrody m.in. jest zachowanie różnorodności biologicznej. Ustawa określa także prawne formy ochrony przyrody, a co za tym idzie ochrony bioróżnorodności. Wśród instrumentów prawnych wymienione są: parki narodowe, rezerwaty przyrody, parki krajobrazowe, obszary chronionego krajobrazu, obszary Natura 2000, stanowiska dokumentacyjne, użytki eko-

19 J. Bucińska, M. Górski, M. Niedziółka, R. Stec, D. Straus, Administracja publiczna - człowiek a ochrona środowiska: Zagadnienia społeczno - prawne, Warszawa 2011, s. 82-92.

20 Ibidem, s. 95.

21 J. Justyński, Harmonizacja polskiego prawa ochrony środowiska ze standardami europejskimi, Warszawa 2002, s. 11.

22 Por. II Polityka ekologiczna państwa, [on-line]: https://www.mos. gov.pl/artykul/329_polityka_ekologiczna/339_II_polityka_ekologiczna.html, [dostęp: 10.05.2015 r.]. 
logiczne, zespoły przyrodniczo-krajobrazowe, ochrona gatunkowa roślin, zwierząt i grzybów ${ }^{23}$. Jest to katalog zamknięty. Co ciekawe, $\mathrm{w}$ porównaniu $\mathrm{z}$ poprzednim stanem prawnym, gdy obowiązywała ustawa o ochronie przyrody z dnia 16 października $1991^{24}$, formy ochrony powiększono o obszary Natura 2000, a także zaliczono grzyby do obszaru chronionego ustawowo. W obecnym stanie prawnym ustawodawca przewidział także możliwość współpracy międzynarodowej w zakresie form ochrony przyrody ${ }^{25}$.

Aby zwiększyć poziom ochrony przyrody podejmowany jest szereg działań legislacyjnych, które tworzą instytucje prawne mające zapewnić zaawansowaną ochronę różnorodności biologicznej. Wśród materiału regulowanego ustawowo są coraz bardziej specjalistyczne dziedziny ochrony środowiska np. ochrona krajobrazu, rolnictwo ekologiczne, międzynarodowe przemieszczanie odpadów. W związku z powyższym można zastanawiać się czy nie następuje przeregulowanie kwestii ochrony środowiska, a także jaka jest efektywność i spójność proponowanych regulacji. Obecnie polski system prawa ochrony środowiska tworzy zbiór kilkudziesięciu (łącznie z umowami międzynarodowymi) ustaw związanych bezpośrednio lub pośrednio z ochroną środowiska i ochroną przyrody ${ }^{26}$.

Dlatego też wymieniając instytucje mające służyć ochronie bioróżnorodności, autor skupił się na najważniejszych z nich, podążając za systematyką zawartą w u.o.p.

\section{PARK NARODOWY}

Na gruncie ustawy o ochronie przyrody, park narodowy jest to obszar wyróżniający się szczególnymi wartościami przyrodniczymi, naukowymi, społecznymi, kulturowymi i eduka-

23 Por. art. 6 ust. 1 u.o.p.

24 Dz.U. 1991 nr 114 poz. 492 z późn. zm.

25 Zob. art. 6 ust. 2 u.o.p.

26 M. Górski (red.), Prawo ochrony środowiska, Warszawa 2014, s. 17-21. 
cyjnymi, o powierzchni nie mniejszej niż 1000 ha, na którym ochronie podlega cała przyroda oraz walory krajobrazowe ${ }^{27}$. Park narodowy jest państwową osobą prawną, do dnia 1 stycznia 2012 mógł być utworzony przez Radę Ministrów w drodze rozporządzenia, a obecnie może to nastąpić w drodze ustawy. Obszar ten kreuje się w celu ochrony różnorodności biologicznej, a także zasobów, tworów i składników przyrody nieożywionej i walorów krajobrazowych, przywrócenia właściwego stanu zasobów i składników przyrody oraz odtworzenia zniekształconych siedlisk przyrodniczych, siedlisk roślin, siedlisk zwierząt lub siedlisk grzybów ${ }^{28}$.

Prawo związane z ograniczeniami działalności człowieka w parkach narodowych jest restrykcyjne, co za tym idzie ogranicza wszelkie przedsięwzięcia mogące negatywnie wpływać na zmianę ekosystemu w obrębie obszaru chronionego. Ustawowym zakazom podlegają m.in.: budowa obiektów budowlanych, chwytania zwierząt dzikich, a także umyślne płoszenie zwierząt, prowadzenie polowania, pozyskiwanie i niszczenie roślin i grzybów, zmiana stosunków wodnych, niszczenie gleby, palenie ognisk, prowadzenie działalności wytwórczej, rolniczej i handlowej, połów ryb, ruch pieszy, rowerowy, motorowy i narciarski poza wyznaczonymi trasami. Przykładów ograniczeń działalności ingerującej w teren parków narodowych jest więcej, a wszystkie te przypadki reguluje art. 15 u.o.p.

$\mathrm{Na}$ obszarach graniczących z parkami narodowymi obowiązkowe jest utworzenie obszaru szczególnie chronionego - otuliny ${ }^{29}$. Zgodnie z art. 5 pkt 14 u.o.p. jest to jest strefa ochronna granicząca z formą ochrony przyrody i wyznaczana indywidualnie dla tej formy $\mathrm{w}$ celu zabezpieczenia przed zagrożeniami zewnętrznymi wynikającymi z działalności człowieka. Wyznaczenie obszaru otuliny parku narodowego następuje w drodze rozporządzenia Rady Ministrów. Otulina może być także utworzona wokół rezerwatu przyrody i parku krajobrazo-

27 Art. 8 ust. 1 u.o.p.

28 J. Ciechanowicz-McLean, Leksykon ochrony środowiska, Warszawa 2009, s. 297-306.

29 Por. art. 11 u.o.p. 
wego (art. 13 ust. 2 i art. 16 ust. 2 u.o.p.). W tych przypadkach jej utworzenie ma charakter fakultatywny.

Najstarszym parkiem narodowym w naszym kraju jest Białowieski Park Narodowy, który został utworzony w 1921 r. Obecnie w Polsce mamy 23 parki narodowe ${ }^{30}$.

\section{REZERWAT PRZYRODY}

Rezerwat obejmuje obszary zachowane w stanie naturalnym lub mało zmienionym, ekosystemy, ostoje i siedliska przyrodnicze, a także siedliska roślin, siedliska zwierząt i siedliska grzybów oraz twory i składniki przyrody nieożywionej, wyróżniające się szczególnymi wartościami przyrodniczymi, naukowymi, kulturowymi lub walorami krajobrazowymi ${ }^{31}$. Ochrona w rezerwacie może dotyczyć całej przyrody lub poszczególnych jej składników, np. fauny, flory lub przyrody nieożywionej. Podobnie jak w przypadku parków narodowych, rezerwat lub jego część może podlegać ochronie: ścisłej, czynnej i krajobrazowej. Rezerwat może posiadać swoją otulinę. Uznanie za rezerwat przyrody następuje w drodze aktu prawa miejscowego, w formie zarządzenia regionalnego dyrektora ochrony środowiska.

\section{PARK KRAJOBRAZOWY}

Park krajobrazowy obejmuje obszar chroniony ze względu na wartości przyrodnicze, historyczne i kulturowe oraz walory krajobrazowe $\mathrm{w}$ celu zachowania, popularyzacji tych wartości w warunkach zrównoważonego rozwoju, może on także posiadać swoją otulinę, a jego utworzenie następuje $\mathrm{w}$ formie

30 J. Ciechanowicz-McLean, Dz. Cyt., s. 13-18.

31 Por. art. 13 ust. 1 u.o.p. 
uchwały sejmiku województwa, na terenie, którego taki park się znajduje ${ }^{32}$.

Parki krajobrazowe, jako forma ochrony przyrody zaczęły powstawać na początku lat 80 . XX wieku, jednak sama koncepcja jest dużo starsza i wskazuje się, że pojawiła się już w latach 60. ubiegłego stulecia ${ }^{33}$.

Pierwsza regulacja ustawowa dotycząca parków krajobrazowych pojawiła się dopiero w 1991 roku. Z jej wprowadzeniem wiązało się wiele kontrowersji. Pierwotnie uważano, że parki krajobrazowe muszą chronić wyłącznie estetyczne przymioty danego terenu. W kolejnych latach zakres ochrony został rozszerzony o środowisko przyrodnicze, co zagwarantowało stworzenie kompleksowej ochrony. Obecnie obowiązująca ustawa o ochronie przyrody z 2004 roku wprowadza dodatkowe kryterium objęcia obszaru ochroną - miejsce takie musi posiadać walory krajobrazowe.

Zgodnie $\mathrm{z}$ artykułem 17 u.o.p. na terenie parku krajobrazowego może nastąpić ograniczenie realizacji przedsięwzięć mogących m.in. znacząco oddziaływać na środowisko ${ }^{34}$, umyślnego zabijania dziko występujących zwierząt, likwidowania i niszczenia zadrzewień, wykonywania prac ziemnych trwale zniekształcających rzeźbę terenu, budowania nowych obiektów budowlanych, organizowania rajdów motorowych i samochodowych.

\section{OBSZAR CHRONIONEGO KRAJOBRAZU}

Obejmuje on tereny chronione ze względu na wyróżniający się krajobraz o zróżnicowanych ekosystemach, wartościo-

32 Art. 18 u.o.p.

33 M. Kistowski, Wybrane aspekty zarządzania ochrona przyrody $w$ parkach krajobrazowych, Poznań 2004, s. 10 i n.

34 W rozumieniu przepisów ustawy z dnia 3 października 2008 r. o udostępnianiu informacji o środowisku i jego ochronie, udziale społeczeństwa w ochronie środowiska oraz o ocenach oddziaływania na środowisko (tekst jedn. Dz. U. z 2013 r. poz. 1235, z późn. zm.). 
we ze względu na możliwość zaspokajania potrzeb związanych z turystyką i wypoczynkiem lub pełnioną funkcją korytarzy ekologicznych ${ }^{35}$. Jest to jedna z najmniej restrykcyjnych powierzchniowych form ochrony przyrody w Polsce. Obejmuje różnej wielkości tereny (zwykle rozległe) obejmujące doliny rzeczne, kompleksy leśne, wzgórza, wydmy, torfowiska ${ }^{36}$. Na terenie obszarów chronionego krajobrazu możliwe jest prowadzenie działalności gospodarczej, z niewielkimi ograniczeniami (np. zakaz niszczenia środowiska, zakaz wznoszenia obiektów szkodliwych dla środowiska). W Polsce istnieje ok. 419 obszarów chronionego krajobrazu, które zajmują około $70500 \mathrm{~km}^{2}$, czyli ponad $23 \%$ powierzchni kraju.

\section{OBSZAR NATURA 2000}

Polski ustawodawca w ramach harmonizacji prawa polskiego z prawem Unii Europejskiej wprowadził także do naszego stanu prawnego obszary Natura 2000. Celem programu jest zachowanie określonych typów siedlisk przyrodniczych oraz gatunków, które uważane są za cenne i zagrożone w skali całej Europy. Konieczność ich utworzenia wynika z wdrożenia dyrektywy Rady z dnia 21 maja 1992 r. w sprawie ochrony siedlisk naturalnych oraz dzikiej fauny i flory. Artykuł 3 ust. 1 dyrektywy przewidział utworzenie spójnej europejskiej sieci ekologicznej pod nazwą Natura 2000, która objęła:

- specjalne obszary ochrony siedlisk tworzone na podstawie tej dyrektywy (w skrócie nazywane obszarami „siedliskowymi” lub „habitatowymi”);

- obszary specjalnej ochrony ptaków (tzw. obszary „ptasie") tworzone w państwach Unii Europejskiej już wcześniej na podstawie dyrektywy 79/409/EWG Rady z dnia 2 kwietnia 1979 r. w sprawie ochrony dzikiego ptactwa, aktualnie wprost zastąpionej dyrektywą Parla-

35 Art. 23 u.o.p.

36 K. Gruszecki, op. cit., s. 53-58. 
mentu Europejskiego i Rady z dnia 30 listopada 2009 r. 2009/147/WE w sprawie ochrony dzikiego ptactwa (zob. art. 18 dyrektywy).

Obecnie w Polsce sieć Natura 2000 zajmuje prawie 20\% powierzchni lądowej kraju. W jej skład wchodzi: 845 obszarów mających znaczenie dla Wspólnoty oraz 145 obszarów specjalnej ochrony ptaków ${ }^{37}$.

\section{POMNIKI PRZYRODY}

Kolejną prawną formą ochrony bioróżnorodności są pomniki przyrody. Są to pojedyncze twory przyrody żywej i nieożywionej lub ich skupiska o szczególnej wartości przyrodniczej, naukowej, kulturowej, historycznej lub krajobrazowej oraz odznaczające się indywidualnymi cechami, wyróżniającymi je wśród innych tworów, okazałych rozmiarów drzewa, krzewy gatunków rodzimych lub obcych, źródła, wodospady, wywierzyska, skałki, jary, głazy narzutowe oraz jaskinie ${ }^{38}$. Co ciekawe, poza obszarem zabudowanym, jeżeli nie stanowi to zagrożenia dla ludzi oraz mienia pomniki są chronione aż do całkowitego rozpadu. Najczęściej pomnikami przyrody zostają drzewa bądź ich skupiska. Ustanowienie pomnika przyrody następuje (po uzgodnieniu z regionalnym dyrektorem ochrony środowiska) w drodze uchwały rady gminy. Uchwała ta powinna zawierać nazwę obiektu, jego położenie, szczególne cele ochrony, obowiązujące zakazy oraz sprawującego nadzór nad pomnikiem przyrody. Z kolei organ sprawujący nadzór obowiązany jest umieścić stosowną tablicę informacyjną.

37 Obszar Natura 2000 w Polsce. [on-line] http://natura2000.gdos.gov. pl/strona/natura-2000-w-polsce, [dostęp: 12.05.2015].

38 Por. Art. 40 ust. 1 u.o.p. 


\section{STANOWISKA DOKUMENTACYJNE ORAZ UŻYTKI EKOLOGICZNE}

Mniejszymi, choć nie bez znaczenia, formami ochrony przyrody na gruncie ustawy o ochronie przyrody są stanowiska dokumentacyjne, a także użytki ekologiczne. Pierwsze z nich są to niewyodrębniające się na powierzchni miejsca występowania formacji przyrodniczych, które są istotne ze względu badawczego lub naukowego np. miejsca tworów geologicznych ${ }^{39}$. Natomiast użytki ekologiczne to zasługujące na ochronę pozostałości ekosystemów mających znaczenie dla zachowania różnorodności biologicznej. Mogą być nimi naturalne zbiorniki wodne, śródpolne i śródleśne oczka wodne, kępy drzew i krzewów, bagna, torfowiska, wydmy, płaty nie użytkowanej roślinności, starorzecza, wychodnie skalne, skarpy, kamieńce, siedliska przyrodnicze oraz stanowiska rzadkich lub chronionych gatunków roślin, zwierząt i grzybów, ich ostoje oraz miejsca rozmnażania lub miejsca sezonowego przebywania ${ }^{40}$.

\section{ZESPOŁY PRZYRODNICZO-KRAJOBRAZOWE}

W art. 43 u.o.p. ustawodawca ustanawia zespoły przyrodniczo-krajobrazowe. Są to fragmenty krajobrazu naturalnego i kulturowego zasługujące na ochronę ze względu na ich walory widokowe lub estetyczne.

Zespół przyrodniczo-krajobrazowy wyznacza się w celu ochrony wyjątkowo cennych fragmentów krajobrazu naturalnego i kulturowego, dla zachowania jego wartości przyrodniczych, kulturowych i estetycznych. Działalność na terenach objętych tą formą ochrony uwarunkowana jest opracowaniem dla nich planu zagospodarowania przestrzennego, który uwzględni postulaty przyrodników i historyków.

39 Art. 41 ust. 1 u.o.p.

40 Art. 42 u.o.p. 


\section{OCHRONA GATUNKOWA ROŚLIN, ZWIERZĄT I GRZYBÓW}

Ochrona gatunkowa, jako ostatnia z omawianych prawnych form ochrony, jaką przewiduje polski ustawodawca, ma na celu zapewnienie przetrwania i właściwego stanu ochrony dziko występujących roślin, grzybów i zwierząt oraz ich siedlisk, a także zachowanie różnorodności gatunkowej i genetycznej. Ochrona ta dotyczy gatunków rzadko występujących, endemicznych, podatnych na zagrożenia i zagrożonych wyginięciem oraz objętych ochroną na podstawie umów międzynarodowych.

Podstawy prawne ochrony gatunkowej ustala ustawa o ochronie przyrody ${ }^{41}$, a szczegółowe jej zasady oraz wykazy gatunków chronionych określa minister właściwy do spraw środowiska w drodze rozporządzenia ${ }^{42}$.

W stosunku do gatunków objętych ochroną gatunkową obowiązują określone zakazy (zabijania, zbierania, przetrzymywania, niszczenia ich siedlisk, handlowania, wywożenia za granicę, płoszenia itp.). Na odstępstwa od zakazów zezwolenie wydaje Generalny Dyrektor Ochrony Środowiska lub regionalny dyrektor ochrony środowiska.

\section{PODSUMOWANIE}

Istnieje wiele instrumentów prawnych służących ochronie różnorodności biologicznej. Ich ustanowienie konieczne jest do ochrony zagrożonych gatunków. Powyższy przegląd traktuje o podstawowych środkach prawnych, warto jednak pamiętać, że istnieją także inne instrumenty prawne, które

41 Por. art. 46 u.o.p.

42 Zob. Rozporządzenie Ministra Środowiska z dnia 12 października 2011 r. w sprawie ochrony gatunkowej zwierząt, Dz. U. z 2011 r. Nr 237, poz. 1419. 
w sposób pośredni lub bezpośredni wpływają na byt gatunków biologicznych.

Bioróżnorodność ma podstawowe znaczenie dla ewolucji oraz trwałości układów podtrzymujących życie w biosferze. W celu ochrony bioróżnorodności konieczne jest przewidywanie, zapobieganie oraz zwalczanie przyczyn zmniejszania się lub jej zanikania. Ubożenie bioróżnorodności wyraża się chociażby poprzez: utratę siedlisk, wymieranie gatunków, zmniejszanie zróżnicowania genowego w populacjach. Zapobieganiu wyniszczania systemu biologicznego, a co za tym idzie bioróżnorodności jest doniosłym zadaniem ze strony administracji państwowej. Dlatego też ustawodawca wyposażył egzekutywę w odpowiednie narzędzia ochronne i co za tym idzie wyznaczył obowiązek ochrony bioróżnorodności w naszym kraju ${ }^{43}$.

Prawne formy ochrony różnorodności biologicznej wymienione $\mathrm{w}$ niniejszym artykule, to środki, dzięki którym ustawodawca chroni określone dobro. Jest nim niewątpliwie bioróżnorodność, a co za tym idzie utrzymanie równowagi w ekosystemie. Bez środków prawnych nie moglibyśmy mówić o faktycznym zapewnieniu ochrony poszczególnym gatunkom. W obecnym stanie prawnym znaczącą rolę odgrywa harmonizacja prawa krajowego z porządkiem Unii Europejskiej i prawem międzynarodowym. Trzeba jednak uznać, że zaawansowane instrumenty jakimi dysponuje administracja państwowa muszą być ciągle rozwijane i dostosowywane do obecnych potrzeb. W ocenie autora, ochrona zapewniana obecnie jest na poziomie satysfakcjonującym, jednakże nie można zapominać o wybieganiu w przyszłość i ochronie gatunków najbardziej zagrożonych wyginięciem. Warto również pamiętać, że harmonizacja prawa krajowego z prawem międzynarodowym może spowodować powstanie nieefektywnych środków ochrony bioróżnorodności, oraz może spowodować nadmierną jurydyzację dziedziny prawa ochrony środowiska. Dlatego też postulatem de lege lata pozostaje efektywność środków, a nie ich mnogość.

43 J. Jendrośka (red. nauk.), M. Bar, Z. Bukowski, J. Jerzmański, S. Urban, Leksykon prawa ochrony środowiska, Warszawa 2012, s. 46-48. 


\section{BIBLIOGRAFIA}

Andrzejewski R., Weigle A., Różnorodność biologiczna Polski, Warszawa 2003.

Bucińska J., Górski M., Niedziółka M., Stec R., Straus D., Administracja publiczna - człowiek a ochrona środowiska: Zagadnienia spoteczno - prawne., Warszawa 2011.

Ciechanowicz-McLean J., Leksykon ochrony środowiska, Warszawa 2009.

Ciechanowicz-McLean J., Prawo i polityka ochrony środowiska, Warszawa 2009.

Górski M., Prawo ochrony środowiska, Warszawa 2014.

Gruszecki K., Ustawa o ochronie przyrody. Komentarz, Warszawa 2013.

Jendrośka J. (red. nauk.), Bar M., Bukowski Z., Jerzmański J., Urban S., Leksykon prawa ochrony środowiska, Warszawa 2012.

Justyński J., Harmonizacja polskiego prawa ochrony środowiska ze standardami europejskimi, Warszawa 2002.

Kistowski M., Wybrane aspekty zarządzania ochrona przyrody w parkach krajobrazowych, Poznań 2004.

Millenium Ecosystem Assessment, MEA 2005.

Wybrane problemy prawa ochrony środowiska, B. Rakoczy, M. Pchałek (red.), Warszawa 2010.

Kontakt e-mail:

kamilstepniak@o2.pl 